\title{
Kesesuaian hasil ultrasonografi dan diagnosis klinis terhadap pemeriksaan histopatologis penderita limfadenitis tuberkulosis regio servikal
}

\author{
Mikhael Aditya $^{1}$ Yopi Simargi ${ }^{2}$
}

\begin{abstract}
ABSTRAK
LATAR BELAKANG

Limfadenopati regio servikal merupakan kasus yang sering terjadi sebagai manifestasi berbagai penyakit, termasuk tuberkulosis. Teknik pemeriksaan kelenjar getah bening yang menjadi standar baku adalah histopatologi. Pemeriksaan non-invasif berupa ultrasonografi (USG) dapat menjadi alternatif untuk menegakkan diagnosis tuberkulosis kelenjar getah bening. Oleh karena itu, penelitian dilakukan untuk mengetahui nilai kesesuaian USG sebagai alat diagnosis limfadenitis tuberkulosis, termasuk nilai akurasi, sensitivitas, spesifisitas, nilai duga positif, dan nilai duga negatif dibandingkan dengan standar baku.

\section{METODE}

Penelitian dilakukan secara deskriptif retrospektif dengan teknik pengambilan sampel potong lintang (cross-sectional) menggunakan 100 rekam medis pasien limfadenopati regio servikal di rumah sakit (RS) Atma Jaya, Jakarta. Waktu pemeriksaan ultrasonografi dan histopatologi pada periode Oktober 2015 hingga Oktober 2017. Analisis data dilakukan untuk mengetahui akurasi, sensitivitas, spesifisitas, nilai duga positif, dan nilai duga negatif, serta tingkat kemaknaan hasil ultrasonografi dan diagnosis klinis dalam mendiagnosis tuberkulosis. Analisis data menggunakan uji proporsi sampel dengan tingkat kemaknaan $\mathrm{p}<0.05$.
\end{abstract}

\section{HASIL}

Sebanyak 59 pasien $(59.0 \%)$ terdiagnosis tuberkulosis berdasarkan pemeriksaan histopatologi. Akurasi, sensitivitas, spesifisitas, nilai duga positif, dan nilai duga negatif ultrasonografi berturut-turut sebesar $69.0 \% ; 59.3 \% ; 83.0 \% ; 83.3 \%$; dan 58.6\%. Pengujian data menunjukkan perbedaan bermakna hasil ultrasonografi terhadap hasil histopatologi $(\mathrm{p}=0.0005)$, sehingga hasil ultrasonografi dianggap belum sesuai secara statistik.

\section{KESIMPULAN}

Ultrasonografi belum dapat menjadi alternatif pilihan untuk menegakkan diagnosis tuberkulosis secara statistik, namun dapat menjadi alat evaluasi tuberkulosis yang baik. Penelitian lebih lanjut masih perlu dilakukan.

Kata kunci : limfadenopati, tuberkulosis, ultrasonografi, histopatologi
${ }^{1}$ Program Studi Sarjana

Kedokteran, Fakultas Kedokteran dan Ilmu Kesehatan, UNIKA Atma Jaya

2 Departemen Radiologi, Fakultas Kedokteran dan Ilmu Kesehatan, UNIKA Atma Jaya

\section{Korespondensi:}

Mikhael Aditya

Program Studi Sarjana Kedokteran, Fakultas Kedokteran dan Ilmu Kesehatan, UNIKA Atma Jaya, Jalan Pluit Raya No.2, Pluit, Jakarta Utara 14440

Email: mikhaeladity@gmail.com Phone: +6287808051948

J Biomedika Kesehat 2019;2(1):20-26 DOI: $10.18051 / J B i o m e d K e s .2019$. v2.20-26

pISSN: 2621-539X / eISSN: 2621-5470

Artikel akses terbuka (open access) ini didistribusikan di bawah lisensi Creative Commons Attribution 4.0 International (CC-BY 4.0) 


\section{ABSTRACT}

\section{The compatibility between ultrasonograph results and clinical diagnosis toward histopathologic examination of cervical tuberculous lymphadenitis patients}

\section{BACKGROUND}

Cervical lymphadenopathy is a common manifestation of wide variations of disease, including tuberculosis. Histopathologic examination remains the gold standard of lymph nodes assessment up until today. As a noninvasive procedures, ultrasonography is one out of many alternatives of lymph nodes assessment to be considered useful for diagnosing tuberculosis, particularly of the lymph nodes. Hence, this study was conducted to find out the compatibility of ultrasonograph result tuberculous lymphadenitis, including the accuracy, sensitivity, specificity, positive, and negative predictive value towards the golden standard.

\section{METHODS}

This descriptive study was conducted retrospectively, with cross-sectional sample retrieval using 100 medical records of cervical lymphadenopathy patients from Atma Jaya hospital, Jakarta which undertook ultrasonography and histopathological examination in between October 2015 to October 2017. Data analysis was conducted to find out accuracy, sensitivity, specificity, positive predictive value, negative predictive value, and the significance of ultrasonography and clinical diagnosis results for diagnosing tuberculous lymph nodes based on the gold standard. Hypothesis testing was using single sample proportion test, with $\mathrm{p}<0.05$ shows a significance difference.

\section{RESULT}

Tuberculosis positive patients was as much as 59 patients $(59.0 \%)$, approved by the histopathology examination. Accuracy, sensitivity, specificity, positive predictive value, and negative predictive value of ultrasonography was found to be $69.0 \% ; 59.3 \% ; 83.0 \% ; 83.3 \%$; and $58.6 \%$ in order. Hypothesis testing show a significance difference between ultrasonography and histopathological results $(\mathrm{p}=0.0005)$. Therefore, ultrasonography examination is considered to be statistically not compatible.

\section{CONCLUSION}

Ultrasonography examination is not having enough evidence to be considered as an alternative standard for diagnosing tuberculous lymph nodes statistically, yet a satisfactory evaluation tools for tuberculous lymph nodes. However, further study is necessary.

Keywords : lymphadenopathy, tuberculosis, ultrasonography, histopathology

\section{PENDAHULUAN}

Limfadenopati adalah keadaan abnormal kelenjar getah bening (KGB) yang ditandai oleh adanya pembesaran dan atau perubahan konsistensi. ${ }^{(1-3)}$ Penelitian oleh Al Kadah, et al. (2014) menunjukkan bahwa insiden limfadenopati pada pasien pediatri dapat mencapai $38-45 \%$ kasus pertahun. ${ }^{(4)}$ Beberapa penelitian memaparkan bahwa regio KGB dengan prevalensi limfadenopati tertinggi adalah regio servikal, berkisar antara 40$74 \%$ dari total seluruh kasus limfadenopati. . $^{(1-3,5)}$ Limfadenopati merupakan gejala suatu penyakit, baik akibat suatu keganasan maupun etiologi penyakit lain yang bukan keganasan. ${ }^{(6)}$ Beberapa penelitian menunjukkan bahwa angka kejadian limfadenopati akibat bukan keganasan lebih tinggi daripada akibat keganasan, dan infeksi menempati urutan teratas. ${ }^{(1,7,8)}$

Infeksi merupakan penyebab limfadenopati regio servikal terbanyak, khususnya di kawasan Asia-Afrika, dengan tuberkulosis (TB) berada pada urutan teratas. ${ }^{(1,3,8)}$ Berdasarkan data World Health Organization (WHO), Indonesia menempati urutan kedua sebagai negara dengan insiden TB tertinggi di dunia pada tahun 2015. ${ }^{(9)}$ Penelitian oleh Lestari, et al. (2011) menunjukkan bahwa $10-15 \%$ kasus TB di pulau Jawa merupakan kasus TB ekstrapulmoner (TBEP) dengan penyebaran tertinggi pada KGB regio servikal. (10) Data tersebut juga didukung oleh penelitian Lee Ji Yeon (2015) yang menyatakan bahwa KGB merupakan salah satu lokasi penyebaran TBEP tertinggi di Korea Selatan. ${ }^{(11)}$ Meskipun demikian, penelitian oleh Gosche and Vick (2006) menunjukkan bahwa infeksi lain seperti bakteri nontuberkulosis, virus, fungi, serta berbagai jenis parasit lain juga diketahui dapat menyebabkan limfadenopati regio servikal pada berbagai kasus. (12)

Etiologi yang beragam memerlukan diagnosis yang tepat. Ultrasonografi (USG) diperkirakan dapat menjadi alat diagnosis alternatif yang mampu menegakkan diagnosis, khususnya tuberkulosis pada kasus-kasus limfadenopati. Penelitian oleh Ahmed, et al. (2013) menunjukkan bahwa USG memiliki sensitivitas sebesar $96.8 \%$ untuk menegakkan diagnosis limfadenitis tuberkulosis. ${ }^{(8)}$ Hasil 
tersebut juga didukung oleh penelitian Ying and Ahuja (2017) yang menunjukkan sensitivitas USG sebesar $98 \%$ dan sepesifisitas sebesar $95 \%$ dalam mendiagnosis limfadenitis tuberkulosis, terlebih dengan kombinasi teknik sitologi aspirasi jarum halus (fine needle aspiration cytology/FNAC). ${ }^{(13)}$ Berdasarkan hal tersebut, USG diharapkan mampu menjadi modalitas alternatif sebagai alat diagnosis limfadenitis tuberkulosis, dengan mengandalkan kemampuan USG untuk melihat karakteristik KGB yang ditunjukkan melalui mesin USG.

Penelitian ini diharapkan mampu menjadi dasar untuk mengembangkan USG sebagai alat diagnosis, terutama pada kasus-kasus TBEP pada KGB, mengingat angka prevalensi yang terbilang tinggi di Indonesia. Pemeriksaan USG juga diharapkan mampu meningkatkan efektivitas pemeriksaan limfadenopati dengan mengandalkan sifatnya yang non-invasif, harga yang relatif lebih murah, risiko yang sangat rendah, serta dapat dilakukan dalam waktu yang singkat. ${ }^{(3,14)}$ Dasar diagnosis limfadenitis tuberkulosis dapat dilihat secara langsung berdasarkan karakteristikkarakteritik KGB yang diperlihatkan melalui hasil USG. ${ }^{(15-17)}$ Terlepas dari hal tersebut, pemeriksaan histopatologi masih merupakan standar baku penegakkan diagnosis limfadenopati saat ini, namun dengan berbagai pertimbangan akibat teknik pengambilan sampel yang invasif, risiko dan efek samping yang lebih tinggi, serta biaya yang lebih mahal, meskipun memiliki nilai diagnostik yang lebih tinggi. ${ }^{(7,18,19)}$

\section{METODE}

\section{Desain dan subjek penelitian}

Penelitian ini dilakukan dengan metode potong lintang menggunakan data retrospektif pada Oktober 2015-Oktober 2017. Data responden dalam penelitian diperoleh melalui 100 rekam medis pasien RS Atma Jaya Jakarta yang telah lulus seleksi kriteria inklusi dan eksklusi penelitian. Adapun kriteria inklusi penelitian antara lain: penderita limfadenopati servikal, pasien RS Atma Jaya Jakarta periode Oktober 2015-Oktober 2017, dan memiliki diagnosis atau suspek yang ditetapkan oleh pemeriksaan klinis, USG, dan histopatologi. Data responden dieksklusikan apabila terdapat satu atau lebih pemeriksaan yang tidak mencantumkan diagnosis atau suspek.

\section{Besar sampel, pengukuran, dan analisis data}

Besar sampel minimal yang dibutuhkan adalah sebanyak 96 sampel. Jumlah tersebut didapatkan dari perhitungan menggunakan rumus besar sampel untuk penelitian potong lintang dengan nilai alfa $(\alpha)$ sebesar 0.05 , nilai presisi (d) 0.1 dan nilai p 0.5 (peneliti belum menemukan penelitian yang sama sebelumnya, sehingga peneliti menggunakan 0.5 sesuai kaidah penggunaan rumus).

Rekam medis yang diperoleh kemudian diobservasi dan dilakukan pencatatan, terutama pada bagian diagnosis atau suspek berdasarkan pemeriksaan klinis, USG, dan histopatologi, serta dicocokkan menggunakan tabel silang $2 \times 2$ secara manual (hasil dapat dilihat pada Tabel 3). Perhitungan nilai diagnostik seperti akurasi, sensitivitas (Sn), spesifisitas (Sp), nilai duga negatif (NDN), dan nilai duga positif (NDP) dilakukan dengan rumus konvensional dan dihitung secara manual. Analisis data menggunakan uji proporsi sampel tunggal (single sample proportion test).

Penelitian ini telah mendapat ijin Departemen Etika Fakultas Kedokteran dan Ilmu Kesehatan Universitas Katolik Indonesia Atma Jaya Jakarta dalam surat No 03/10/KEPFKUAJ/2017.

\section{HASIL}

\section{Karakteristik responden}

Tabel 1. Distribusi demografi responden penelitian

\begin{tabular}{lcc}
\hline & Jumlah (n) & Persentase (\%) \\
\hline Jenis kelamin & & \\
Laki-laki & 40 & 40.0 \\
Perempuan & 60 & 60.0 \\
Total & $\mathbf{1 0 0}$ & $\mathbf{1 0 0 . 0}$ \\
Usia (tahun) & & \\
Anak-anak & & \\
dan remaja & 4 & 4.0 \\
$0-4$ & 3 & 3.0 \\
$5-9$ & 5 & 5.0 \\
$10-14$ & 11 & 11.0 \\
$15-19$ & 15 & 15.0 \\
Dewasa & 15 & 15.0 \\
$20-24$ & 11 & 11.0 \\
$25-29$ & 9 & 9.0 \\
$30-34$ & 8 & 8.0 \\
$35-39$ & 6 & 6.0 \\
$40-44$ & 4 & 4.0 \\
$45-49$ & 4 & 4.0 \\
$50-54$ & 2 & 2.0 \\
$55-59$ & & \\
$60-64$ & 3 & 3.0 \\
Lansia & & \\
$>65$ & $\mathbf{1 0 0}$ & \\
Total & & \\
\hline
\end{tabular}

Keterangan: $n=$ jumlah sample 
Data hasil penelitian menunjukkan bahwa $40(40.0 \%)$ responden adalah laki-laki dan 60 $(60.0 \%)$ perempuan. Rentang usia reponden tersebut beragam, mulai dari rentang usia di bawah empat tahun, sebanyak 4 (4.0\%) responden, hingga rentang usia di atas 65 tahun sebanyak 3 (3.0\%) responden. Frekuensi tertinggi terlihat pada responden dalam kelompok rentang usia 2024 tahun dan 25-29 tahun dengan masing-masing sebanyak 15 (15.0\%) responden.

Berdasarkan hasil diagnosis akhir menurut pemeriksaan histopatologis, bakteri Mycobacterium tuberculosis ditemukan pada 38 (38.0\%) kasus, diikuti oleh limfadenitis kronik nonspesifik sebanyak 21 (21.0\%). Meskipun hasil diagnosis tuberkulosis hanya didapatkan pada 38 kasus, peneliti merasa perlu untuk mempertimbangkan gejala penyakit, hasil-hasil pemeriksaan secara menyeluruh, serta rencana tatalaksana yang dilakukan terhadap pasien.

Berdasar hal tersebut, peneliti memutuskan untuk mengikutsertakan limfadenitis kronik granulomatosa (sebanyak 20 kasus; 20.0\%) dan skrofuloderma tuberkulosis (sebanyak 1 kasus $=1.0 \%$ ) karena kedua penyakit tersebut dicurigai akibat etiologi yang sama, yaitu tuberkulosis. Oleh karena itu, peneliti menetapkan bahwa jumlah kasus tuberkulosis pada penderita limfadenopati regio servikal sebesar 59 (59.0\%) kasus.

Peneliti juga menemukan etiologi lain pada responden dengan limfadenopati regio servikal, seperti neoplasma jinak, ganas, serta metastasis sel kanker, meskipun dalam jumlah yang relatif rendah. Namun demikian, peneliti juga menemukan dua (2.0\%) kasus dengan temuan hasil histopatologi normal yang mungkin memerlukan pemeriksaan lanjutan.

Diagnosis limfadenitis tuberkulosis yang didapatkan berdasarkan perspektif pemeriksaan klinis, USG, dan histopatologi menunjukkan hasil yang beragam. Perbedaan ini mencakup jumlah dan proporsi kasus tuberkulosis pada masing-masing pemeriksaan. Hasil diagnosis TB positif ditemukan sebanyak $63(63.0 \%)$ kasus berdasarkan pemeriksaan klinis, $42(42.0 \%)$ kasus melalui pemeriksaan USG, dan 59 (59.0\%) kasus melalui pemeriksaan histopatologis. Oleh karena itu, penegakan diagnosis TB positif paling banyak diperoleh melalui pemeriksaan klinis.
Tabel 2. Karakteristik penyakit responden dengan limfadenopati regio servikal berdasarkan pemeriksaan baku (histopatologi)

\begin{tabular}{lll}
\hline \multicolumn{1}{c}{ Hasil diagnosis kerja } & (n) & (\%) \\
\hline Limfadenitis kronik granulomatosa & 20 & 20.0 \\
Sialoadenitis kronik nonspesifik & 2 & 2.0 \\
Limfadenitis kronik granulomatosa & & \\
yang disebabkan oleh & 38 & 38.0 \\
mycobacterium tuberculosis & & \\
Fibroadenoma mammae & 1 & 1.0 \\
Lipoma & 1 & 1.0 \\
Kista limfoid nonspesifik & 1 & 1.0 \\
Hiperplasia parakorteks dan folikel & 1 & 1.0 \\
reaktif & 21 & 21.0 \\
Limfadenitis kronik nonspesifik & 2 & 2.0 \\
Dalam batas normal & 2 & 2.0 \\
Metastasis karsinoma papiler & 1 & 1.0 \\
thyroid & 1 & 1.0 \\
Skrofuloderma & 1 & 1.0 \\
Keganasan selubung saraf perifer & 1 & 1.0 \\
Limfoma maligna nonhodgkin & 1 & 1.0 \\
Adenokarsinoma & 1 & 1.0 \\
Limfadenitis struma nudosa & 1 & 1.0 \\
Limfoma maligna Hodgkin & 1 & 1.0 \\
Lesi jinak parotis & 1 & 1.0 \\
Kista struma adenomatosa & 1 & 1.0 \\
Metastasis jaringan tidak diketahui & 1 & 1.0 \\
Kista atheroma dengan peradangan & 100 & 100.0 \\
Karsinoma nasofaring & \\
Total & &
\end{tabular}

Keterangan: $n=$ jumah sample, $\%=$ presentase

\section{Analisis bivariat antara hasil pemeriksaan USG dan klinis terhadap hasil pemeriksaan histopatologis}

Berdasarkan hasil analisis bivariat melalui tabel silang 2x2 dan rumus konvensional, dapat diketahui nilai akurasi, sensitivitas ( $\mathrm{Sn}$ ), spesifisitas (Sp), nilai duga negatif (NDN), dan nilai duga positif (NDP) pemeriksaan klinis dan USG, terhadap pemeriksaan histopatologi sebagai standar baku. Hasil analisis diagnosis klinis menunjukkan nilai akurasi, Sn, Sp, NDN, dan NDP berturut-turut sebesar $70.0 \%, 78.0 \%, 58.5 \%$, $73.0 \%$, dan $64.8 \%$. Sementara itu, hasil analisis USG menunjukkan nilai $69.0 \%, 59.3 \%, 83.0 \%$, $58.6 \%$, dan $83.3 \%$ dalam urutan yang sama (tabel silang dapat dilihat pada Tabel 3).

Hasil uji hipotesis menggunakan proporsi sampel tunggal menunjukkan nilai yang berbeda antara hasil pemeriksaan USG dan diagnosis klinis. Uji hipotesis pemeriksaan USG menunjukkan nilai $\mathrm{p}=0.0005 \quad(\mathrm{p}<0.05)$ yang menunjukkan perbedaan bermakna antara hasil USG dan standar baku. Sementara itu, hasil uji hipotesis diagnosis klinis menunjukkan nilai $\mathrm{p}=0.4161(\mathrm{p} \geq 0.05)$ yang 
Tabel 3. Kesesuaian hasil pemeriksaan limfadenopati servikal antara diagnosis klinis dan histopatologi \& antara USG dan histopatologi

\begin{tabular}{|c|c|c|c|c|}
\hline & & \multicolumn{2}{|c|}{ Histopatologi } & \multirow[b]{2}{*}{$\begin{array}{l}\text { Total } \\
\text { n }(\%)\end{array}$} \\
\hline & & $\begin{array}{c}\text { Bukan Tuberkulosis } \\
\text { n (\%) }\end{array}$ & $\begin{array}{c}\text { Tuberkulosis } \\
\text { n (\%) }\end{array}$ & \\
\hline \multirow{3}{*}{$\begin{array}{l}\text { Diagnosis } \\
\text { Klinis }\end{array}$} & $\begin{array}{c}\text { Bukan Tuberkulosis } \\
\mathrm{n}(\%)\end{array}$ & $24(24.0)$ & $13(13.0)$ & $37(37.0)$ \\
\hline & $\begin{array}{l}\text { Tuberkulosis } \\
\text { n (\%) }\end{array}$ & $17(17.0)$ & $46(46.0)$ & $63(63.0)$ \\
\hline & Total & $41(41.0)$ & $59(59.0)$ & $100(100.0)$ \\
\hline \multirow{3}{*}{ USG } & $\begin{array}{c}\text { Bukan Tuberkulosis } \\
\text { n (\%) }\end{array}$ & $34(34.0)$ & $24(24.0)$ & $58(58.0)$ \\
\hline & Tuberkulosis & $7(7.0)$ & $35(35.0)$ & $42(42.0)$ \\
\hline & Total & $41(41.0)$ & $59(59.0)$ & $100(100.0)$ \\
\hline
\end{tabular}

Keterangan: $n=$ jumlah sample

menunjukkan tidak adanya perbedaan bermakna antara kedua variable uji. Berdasarkan hasil tersebut memperlihatkan bahwa pemeriksaan USG tunggal belum terbukti secara statistik mampu menjadi alat diagnostik alternatif dalam mendiagnosis limfadenitis tuberkulosis servikal menggantikan pemeriksaan histopatologi sebagai standar baku pemeriksaan limfadenopati saat ini.

\section{PEMBAHASAN}

Berdasarkan hasil pengumpulan data di departemen Patologi Anatomi diperoleh 246 rekam medis dalam waktu dua tahun, hanya 100 rekam medis yang memenuhi kriteria inklusi dan eksklusi. Data tersebut memperlihatkan bahwa penggunaan USG dan pemeriksaan histopatologi pada kasus limfadenopati regio servikal belum menjadi prioritas atau pilihan yang populer bagi dokter maupun pasien di RS Atma Jaya Jakarta.

Selain hal tersebut di atas, rata-rata eksklusi responden terjadi akibat rendahnya penggunaan USG, baik akibat tidak digunakannya USG, tidak adanya diagnosis atau suspek yang dicantumkan pada lembar bacaan USG, atau penggunaan alternatif lain seperti CT Scan atau foto polos dada (chest X-Ray/CXR). Terdapat beberapa alasan terjadinya eksklusi responden. Seringkali hasil diagnosis atau suspek semata menurut hasil pemeriksaan USG tidak dicantumkan. Hal ini dapat terjadi karena status USG yang saat ini memang bukan merupakan alat diagnosis, sehingga hasil yang dicantumkan pada lembar bacaan hanya hasil follow up atau evaluasi terapi tanpa perkiraan diagnosis atau suspek etiologi limfadenopati di awal.

Penelitian oleh Ahmed, et al. (2013) ${ }^{(8)}$ dan Geldmacher, et al. (2002)(20) memperlihatkan bahwa dokter lebih menyukai penggunaan $\mathrm{CT}$ Scan daripada USG dalam kasus sehari-hari. Selain itu, penggunaan USG biasanya dilakukan apabila terdapat kecurigaan keganasan oleh dokter yang bersangkutan atau sebagai alat evaluasi pengobatan saja, mengingat kemampuan pencitraan USG yang lebih spesifik pada kasus keganasan pada KGB. Selain itu, penggunaan CXR juga lebih diprioritaskan oleh dokter apabila terdapat kecurigaan TB. Hal ini mengingat kasus TBEP seringkali menyebar dari fokus utama di paru-paru. Oleh karena itu, penegakkan TB pada paru-paru seringkali sudah cukup untuk menegakkan diagnosis TB keseluruhan sehingga tidak memerlukan pemeriksaan USG sebagai tambahan.

Sejauh pengetahuan peneliti, belum ada data yang memperlihatkan hubungan bermakna antara karakteristik responden dengan risiko terjadinya limfadenitis tuberkulosis. Akan tetapi, beberapa penelitian menyatakan bahwa karakteristik responden mungkin dapat menjadi faktor risiko terjadinya penyakit tuberkulosis. $(3,4,6)$ Penelitian tersebut menunjukkan bahwa jenis kelamin perempuan memiliki prevalensi yang lebih tinggi daripada laki-laki, dengan perbandingan 3:2. Prevalensi pada usia dewasa juga terlihat lebih tinggi daripada usia anak-anak dan remaja, serta lansia.

Hasil penelitian menunjukkan bahwa $59.0 \%$ kasus limfadenopati servikal responden di RS Atma Jaya Jakarta adalah TBEP. Hal ini 
tentunya mendukung penelitian sebelumnya oleh Halder, et al. (2016) ${ }^{(1)}$ dan Ahmed, et al. (2013) $)^{(8)}$ yang menunjukkan prevalensi tuberkulosis yang tinggi dibandingkan dengan negara lain di Asia. Hasil penelitian sebelumnya juga menunjukkan hal yang sama, mengenai tingginya jumlah kasus limfadenitis tuberkulosis servikal di Indonesia, khususnya di pulau Jawa. ${ }^{(10)}$

Pemeriksaan USG nampaknya belum dapat dijadikan alat diagnosis tunggal bagi penderita limfadenitis tuberkulosis, meskipun penelitian Ying and Ahuja (2017) menunjukkan nilai diagnostik yang tinggi. ${ }^{(13)}$ Perbedaan ini dapat dikaitkan dengan intervensi teknik FNAC yang diikutsertakan dalam penelitian. Menurut Ghafoori, et al. (2015), FNAC memiliki nilai Sn dan Sp yang tinggi, yaitu sebesar 93.1\% dan $100 \%$ beruturt-turut. ${ }^{(18)}$ FNAC adalah suatu teknik sitopatologi yang kualitasnya hampir sama dengan pemeriksaan histopatologi sehingga kemampuan diagnostik yang dimiliki juga cukup baik. Hal ini tentu tidak dapat dibandingkan dengan penggunaan USG tunggal yang tidak dapat melihat jaringan secara langsung. Oleh karena itu, pemeriksaan USG tunggal belum dapat menjadi alternatif alat diagnostik yang dapat direkomendasikan untuk mendiagnosis tuberkulosis, khususnya limfadenitis tuberkulosis. ${ }^{(21)}$

Faktor lain yang melemahkan potensi USG sebagai alternatif diagnostik adalah ketiadaan ciri khas atau pathognomonic features yang dapat menegakkan secara pasti bahwa suatu limfadenopati disebabkan oleh tuberkulosis. ${ }^{(22)}$ Meskipun dapat memberikan gambaran yang cukup detail akan karaktristik KGB, tetapi masih dibutuhkan beberapa fitur yang harus ditemukan bersamaan untuk menegakkan diagnosis tuberculosis secara pasti, seperti terlihatnya nodus hipoekoik dengan ekogenisitas heterogen, batas nodus yang kurang tegas, nodal mating, abses intranodal, serta perubahan vaskularisasi KGB. Diagnosis limfadenitis tuberkulosis dapat ditegakkan dengan lebih pasti apabila gambaran hasil USG menunjukkan lebih dari dua karakteristik tersebut secara bersamaan. ${ }^{(21,23)}$ Selain fitur tipikal tuberkulosis tersebut, adapula fitur lain pada limfadenitis tuberkulosis yang sekilas mirip denga karakteristik limfadenopati akibat penyakit keganasan, yang kemudian disebut fitur atipikal. Fitur atipikal ini meliputi bentuk yang lebih bulat, adanya perubahan karakteristik hilum $\mathrm{KGB}$, serta perubahan vaskularisasi yang abstrak di sepanjang batas KGB. Hal tersebut tentu dapat membingungkan operator serta dokter dalam menegakkan diagnosis, dan secara tidak langsung mengurangi popularitas USG.

Keterbatasan penelitianiniantaralain besar sampel yang dieksklusikan mengurangi sebagian besar jumlah responden yang diikutsertakan dalam penelitian. Jenis penelitian seperti ini tentu akan lebih berkualitas apabila memiliki jumlah sampel yang lebih besar. Keterbatasan lainnya yaitu adanya bias yang dapat terjadi pada rekam medis. Bias tersebut dapat terjadi akibat beberapa diagnosis yang mungkin tumpang tindih dan saling memengaruhi.

\section{KESIMPULAN}

Hasil penelitian menunjukkan jumlah penggunaan USG dan pemeriksaan histopatologis yang rendah untuk mendiagnosis limfadenitis tuberkulosis di RS Atma Jaya Jakarta. Hal ini cukup penting mengingat pemeriksaan histopatologis merupakan standar baku pemeriksaan limfadenopati, termasuk limfadenitis tuberkulosis. Pemeriksaan USG nampaknya belum dapat dibuktikan mampu secara statistik untuk menjadi alternatif pilihan dalam mendiagnosis limfadenitis tuberkulosis. Meskipun demikian, pemeriksaan USG dapat tetap dipertimbangkan mengingat kemampuannya yang cukup baik untuk melihat karakteristik KGB, biaya yang lebih murah, risiko dan efek samping yang rendah, serta sifatnya yang noninvasif. Penelitian lebih lanjut dibutuhkan untuk meningkatkan validitas masingmasing teknik pemeriksaan dan meningkatkan kualitas penelitian.

\section{UCAPAN TERIMA KASIH}

Penulis mengucapkan terima kasih kepada dr.Yopi Simargi,Sp.Rad dan Dr.dr.C. Murtono, Sp.PA atas bimbingannya selama pengumpulan data dan penulisan naskah ini.

\section{KONFLIK KEPENTINGAN}

Penulis menyatakan tidak ada konflik kepentingan.

\section{DAFTAR REFERENSI}

1. Halder S, Saha B, Sarkar D, et al. Etiological study of generalized lymphadenopathy in a tertiary care hospital. Int J Res Med Sci 2016;4(8):3542- 
8. DOI: 10.18203/2320-6012.ijrms20162327. Available from: https://pdfs.semanticscholar.org/ d95d/68d735d06103cfb6afa2fd241b1e 7774d2b6. pdf

2. Papadopouli E, Michailidi E, Papadopoulou E, et al. Cervical lymphadenopathy in childhood epidemiology and management. Pediatr Hematol Oncol. 2009;26(6):454-60. DOI: 10.1080/08880010903091848. Available from: https:/europepmc.org/abstract/med/19657996

3. Mohseni S, Shojaiaefard A, Khorgami Z, et al. Peripheral lymphadenopathy: Approach and diagnostic tools. Iran J Med Sci. 2014, 39(2 Suppl):158-70. Available from: https://www.ncbi. nlm.nih.gov/pubmed/24753638

4. Al Kadah B, Popov H, Schick B, et al. Cervical lymphadenopathy: Study of 251 patients. Eur Arch Otorhinolaryngol. 2014;272(3):745-52. DOI: 10.1007/s00405-014-3315-9. Available from: https://www.ncbi.nlm.nih.gov/pubmed/25294051

5. Qadri SK, Hamdani NH, Shah P, et al. Profile of lymphadenopathy in Kashmir Valley: A cytological study. Asian Pac J Cancer Prev. 2012;13(8):36215. DOI: 10.7314/APJCP.2012.13.8.3621. Available from: https://www.ncbi.nlm.nih.gov/ pubmed/23098444

6. Ferrer R. Lymphadenopathy: Differential diagnosis and evaluation. Am Fam Physician. 1998;58(6):1313-20. Available from: https://www. aafp.org/afp/1998/1015/p1313.html

7. Leung A, Davies H. Cervical lymphadenitis: Etiology, diagnosis, and management. Curr Infect Dis Rep [Internet]. 2009;11(3):183-9. Available from: https://www.ncbi.nlm.nih.gov/ pubmed/19366560

8. Ahmed I, Hashmi S, Tanwir F, et al. Tuberculosis and cervical lymphadenopathy-a study of 175 cases in a tertiary care hospital. Journal of Oral Hygiene \& Health. 2013;01(03):1-3. Available from: https:// www.omicsonline.org/open-access/tuberculosisand-cervical-lymphadenopathya-study-of-casesin-a-tertiary-care-hospital-2332-0702.1000119. php?aid=21901

9. Tuberculosis (TB) [Internet]. World Health Organization. 2017 [cited 8 April 2017]. Available from: http://www.who.int/mediacentre/factsheets/ fs $104 / \mathrm{en} /$

10. Lestari T, Probandari A, Hurtig A, et al. High caseload of childhood tuberculosis in hospitals on Java Island, Indonesia: A cross sectional study. BMC Public Health [Internet]. 2011;11(1). Available from: https://www.ncbi.nlm.nih.gov/ pmc/articles/PMC3204263/

11. Lee JY. Diagnosis and treatment of extrapulmonary tuberculosis. Int J Tuberc Lung Dis. 2015;78(2):47. DOI: $10.4046 /$ trd.2015.78.2.47 Available from: https://www.ncbi.nlm.nih.gov/pmc/articles/ PMC4388900/

12. Gosche J, Vick L. Acute, subacute, and chronic cervical lymphadenitis in children. Semin Pediatr Surg. 2006;15(2):99-106. DOI: 10.1053/j.sempedsurg.2006.02.007. Available from: https://pdfs.semanticscholar.org/ bec2/594b8d6dce5853e24c9af036bc84065fd023. pdf

13. Ying M, Ahuja A. Ultrasonography of cervical lymph nodes [Internet]. Diir.cuhk.edu.hk. [cited 22 March 2017]. Available from: http://www.diir. cuhk.edu.hk/specials/lymph nodes/lymph nodes. htm\#sonographic

14. Asai S, Miyachi H, Suzuki K, et al. Ultrasonographic differentiation between tuberculous lymphadenitis and malignant lymph nodes. J Ultrasound Med. 2001;20(5):533-38. DOI: 10.7863 jum.2001.20.5.533. Available from: https://www.ncbi.nlm.nih.gov/pubmed/11345111

15. Ying $M$, Bhatia $K$, Lee $Y$, et al. Review of ultrasonography of malignant neck nodes: greyscale, doppler, contrast enhancement and elastography. Cancer Imaging. 2013;13(4):658-69. DOI: $10.1102 / 1470-7330.2013 .0056$. Available from: https://www.ncbi.nlm.nih.gov/pmc/articles/ PMC3894696/

16. Ying M, Lee YYP, Wong KT et al. Ultrasonography of neck lymph nodes in children. HK J Paediatr (new series). 2009;14:29-36. Available from: https://docplayer.net/23433097-Ultrasonographyof-neck-lymph-nodes-in-children.html

17. Ahuja A, Ying M. Sonography of neck lymph nodes. Part II: Abnormal lymph nodes. Clin Radiol. 2003;58(5):359-66. DOI: 10.1016/S00099260(02)00585-8. Available from: https://www. ncbi.nlm.nih.gov/pubmed/12727163

18. Ghafoori M, Azizian A, Pourrajabi $Z$, et al. Sonographic evaluation of cervical lymphadenopathy; comparison of metastatic and reactive lymph nodes in patients with head and neck squamous cell carcinoma using gray scale and doppler techniques. Iran J Radiol. 2015;12(3). DOI: 10.5812/iranjradiol.11044. Available from: https://www.ncbi.nlm.nih.gov/pmc/articles/ PMC4623781/

19. Göret C, Göret EN, Özdemir ZT, et al. Diagnostic value of fine needle aspiration biopsy in nonthyroidal head and neck lesions: A retrospective study of 866 aspiration materials. Int J Clin Exp Pathol. 2015; 8(8): 8709-16. Available from: https://www.ncbi.nlm.nih.gov/pmc/articles/ PMC4583847/

20. Geldmacher H, Taube C, Kroeger C, et al. Assessment of lymph node tuberculosis in Northern Germany. Chest. 2002;121(4):1177-82. DOI: $10.1378 /$ chest.121.4.1177. Available from: https://www.ncbi.nlm.nih.gov/pubmed/11948050

21. Moon I, KimD, BaekH. Ultrasound-based diagnosis for the cervical lymph nodes in a tuberculosisendemic area. Laryngoscope. 2014;125(5):11137. DOI: 10.1002/lary.25030. Available from: https://pdfs.semanticscholar.org/3bd0/ bc87bb15586b331bf975c96eb60db032b441.pdf

22. Pandey A, Kureel S, Pandey J. Chronic cervical lymphadenopathy in children: Role of ultrasonography. J Indian Assoc Pediatr Surg. 2012;17(2):58. DOI: 10.4103/0971-9261.93963. Available from: https://www.ncbi.nlm.nih.gov/ pmc/articles/PMC3326823/

23. Park J, Kim D. Sonographic diagnosis of tuberculous lymphadenitis in the neck. J Ultrasound Med. 2014;33(9):1619-26. DOI: 10.7863/ultra.33.9.1619. Available from: https:// www.ncbi.nlm.nih.gov/pubmed/25154944 